\title{
ADVANTAGES OF LOGISTICS GUARANTEE SYSTEM
}

\author{
CSarimsakov A., Ph.D., Andijan Machine Building Institute, Andijan, Uzbekistan,info@andmi.uz \\ CGaffarov M., Andijan Machine Building Institute, Andijan, Uzbekistan, gaffarov1234@mail.ru
}

\section{ПРЕИМУЩЕСТВА СИСТЕМЫ ЛОГИСТИЧЕСКИХ ГАРАНТИЙ}

\author{
(ССаримсаков А. М., канд. экон. наук, Андижанский машиностроительныий институт, \\ 2. Андижан, Узбекистан, info@andmi.uz
}

(СГаффаров М. Т., Андижанский машиностроительный институт, 2. Андижан, Узбекистан, gaffarov1234@mail.ru

Abstract. The introduction of a system of logistic guarantees in the national economy ensures the stability of products and services and products of new marketing research, a complete study of the consumption of each product (technical, food and other products) that guarantee its production, and prevent mistakes in the country's development process, and also the bankruptcy of firms. The provision of necessary goods and services for each region is guaranteed; production of unnecessary goods is prevented.

Аннотация. Внедрение системы логистических гарантий в народном хозяйстве обеспечивает стабильность услуг и продуктов новых маркетинговых исследований, полное изучение потребления каждого продукта (технических, пищевых и других продуктов), гарантирующих его производство, предотвратить ошибки в процессе развития страны, а также банкротство фирм. Предоставление необходимых товаров и услуг для каждого региона гарантировано, предотвращается производство ненужных товаров.

Keywords: logistics, goods, warranty, economy.

Ключевые слова: логистика, товары, гарантия, экономика хозяйства.

When analyzing the results of a year, the quality of the product is low, and the price is milled. In this case, the main issue is that the reason is that due to the logistic system development or vice versa, there is a drop in prices due to the excessive demand for the market. It is the real demand and supply balance, which determines the amount of production due to any marketing research, ensures its logistical guarantee, fulfils this plan and, in general, satisfies consumers and producers' demands without wasting it.

The urgency of the subject: It is no secret that today, many entrepreneurs produce defective products. On the contrary, it is clear that the rise in prices in the markets without the demand for human consumption is a source of concern for people. It is a logistic guarantee of the development of the country's development of the logistics guarantee of the manufacturer and the protection of the manufacturer from defaults, and the proper determination of its capacity for the product to be settled by the customer is a prerequisite for managing the logistics guarantee as a system, it will force you to look for new products. This situation has a great impact on the development of countries by providing a regional oversight of the region, providing manufacturers with a logistical 
logistics guarantee, and making it a stronger system. It allows manufacturers to create new products without breaking them [1-9].

Exiting the issue: Throughout the year researcher's work in the system. The price of the products, the production of regional products instead of the imported products, it will allow the country to grow. Understanding and achieving any logistics guarantee will protect the manufacturer from defaults. At the same time, logistic guarantees are mainly part of public administration bodies, while they are mainly consumers. The manufacturer cannot get income. This is followed by a very large capital 'freezing'. This is a great opportunity to become a strong logistics guarantor organization. The main objective of the logistics guaranteeing the organization is to determine the cost limit in the region, to provide a logistic price for products and items that are high and provide a logistical guarantee for its cost.

It is recommended that you report under Table to create a guaranteed system of products, sold in the country, region, and city.

Table.

SYSTEM OF PRODUCTS, SOLD IN THE COUNTRY, REGION, AND CITY (example)

\begin{tabular}{llcccccc}
\hline № & Product name & $\begin{array}{c}\text { INN } \\
\text { code }\end{array}$ & $\begin{array}{c}\text { Per } \\
\text { population } \\
\text { income }\end{array}$ & $\begin{array}{c}\text { Volume, } \\
\text { pcs, aton }\end{array}$ & Satisfaction & $\begin{array}{c}\text { Guaranteed } \\
\text { volume }\end{array}$ & $\begin{array}{c}\text { Producer } \\
\text { penalty, } \%\end{array}$ \\
\hline 1 & Ravon automobile & 20234 & $60 / 100$ & 1000 & 1200 & 200 & 16 \\
2 & Cotton fiber & 12 & 8.87 & 2750 & 2200 & 500 & 18.8 \\
3 & Apple & 123 & 38 & 1178 & 1300 & 250 & 19.2 \\
\hline
\end{tabular}

From this Table, it is necessary to conclude a logistic guarantees contract for the export of the product to be exported after crossing the border. The Guarantee Agreement shall be concluded with the provincial governor and shall be subject to registration by the department. If the conditions of the Contract are met by the manufacturer, the percentage of the price of the product at the customer's site at that time shall be determined by the following formula:

$\mu k=\frac{M e m}{M t m} \%$ Percentage of getting expensive,

$-\mathrm{M}_{\mathrm{em}}$ - the amount of the product that is not sold under the terms of the contract;

$-\mathrm{M}_{\mathrm{tm}}$ - saturation limit of the product.

The penalty charges fines for the manufacturer:

$\mathrm{J}^{\mathrm{i} / \mathrm{ch}}=\mu k * \operatorname{Mem}(\mathrm{m}$. sum).

However, if the product is refused to accept because of the costumer's fault:

$\mu a=\frac{M k m}{M t m} \%$ - discount rate,

$-\mathrm{M}_{\mathrm{km}}$ - under the terms of the contract, the volume of the purchased product is not collected by the customer.

Then, each product in the production of the desired size is achieved. Most importantly, the number of bankrupt decreases. Bankruptcy is prevented and other products will be produced. The logistics guaranteed organization will have its income and expense. There is a certain income rate in the price rises and the cost of logistics guaranteed product based on a certain percentage of the damage should be compensated. In both cases, a valid balance report should be provided. The main task of this organization is to maintain logistic guarantee by setting up a warranty agreement for product detection and additional product processing, as well as controlling the prices. Logistics guarantor organization of regional areas and each area is desirable to cover. It is better 
than the authority should check and discuss its balance. Logistics guarantees for the industry will contribute to the development of this sector. It is possible to build a fund for new investment projects. At the market, the seller who raises the price listens to paying him out and refrains from carrying it. It is possible that a new producer can be noticed to economically protect and improve his initiative in order to get a high result. In a word, the organization is now in power, but there is no legitimate request because of the lack of reporting.

With the introduction of a guaranteed logistics system in the system for the organization of buses, the cost of the bus can be covered by the proceeds from the price tax on the passenger and freight prices.

The following steps must be taken to create a logistics guarantee system:

-development of the regional system of logistics guaranteed system;

-integrating the system with qualified economists and lawyers;

-establishment of divisions of the separate logistics guarantees system for agriculture;

-develop a regional governance system that provides a guaranteed system and approve it from the Ministry of Justice;

-developing the rights and responsibilities of the security system specialists;

-development of the tables of the performance of all the organizations producing the products, identifying indicators;

-registration of a territory as a company.

\section{Список литературы:}

1. Саматов Г. А., Камильджанов Б. И., Галимова Ф. Г. Концепции и модели логистического управления. Ташкент: Наука и техника, 2015. С. 227.

2. Бутаев Ш. А., Сидикназаров В. М., Муродов А., Кузиев А. О. Логистика (Управление цепочками поставок). Ташкент: Экстремум-ПРЕССА, 2012. 577 с.

3. Третьякова А. П., Зыков О. А. Логистика. Тюмень, 2010. 269 с.

4. Гаджинский А. М. Логистика. М.: Маркетинг, 1999. 228 с.

5. Левкин Г. Г. Логистика: теория и практика. Ростов-на-Дону: Феникс, 2009. 221 с.

6. Миротин Л. Б. Транспортная логистика. М.: Экзамен, 2002. 512 с.

7. Лукинский В. С. Модели и методы теории логистики. СПБ.: Питер, 2007. 448 с.

8. Лавриков И. Н., Пеньшин Н. В. Транспортная логистика. Тюмень: ТГТУ, 2016. 92 с.

9. Дыбская В. В., Зайцев Е. И., Сергеев В. И., Стерликова А. Н. Логистика. Интеграция и оптимизация логистических бизнес-процессов в цепях поставок. М.: ЭКСМО, 2011. 981 с.

\section{References:}

1. Samatov, G. A., Kamildzhanov, B. I., \& Galimova, F. G. (2015). Kontseptsii i modeli logisticheskogo upravleniya. Tashkent, Nauka i tekhnika, 227.

2. Butaev, Sh. A., Sidiknazarov, V. M., Murodov, A., \& Kuziev, A. O. (2012). Logistika (Upravlenie tsepochkami postavok). Tashkent, Ekstremum-PRESSA, 577.

3. Tretyakova, A. P., \& Zykov, O. A. (2010). Logistika. Tyumen, 269.

4. Gadzhinskii, A. M. (1999). Logistika. Moscow, Marketing. 228.

5. Levkin, G. G. (2009). Logistika: teoriya i praktika. Rostov-on-Don, Feniks, 221.

6. Mirotin, L. B. (2002). Transportnaya logistika. Moscow, Ekzamen, 512.

7. Lukinskii, V. S. (2007). Modeli i metody teorii logistiki. St. Petersburg, Piter, 448.

8. Lavrikov, I. N., \& Penshin, N. V. (2016). Transportnaya logistika. Tyumen, 92. 
9. Dybskaya, V. V., Zaitsev, E. I., Sergeev, V. I., \& Sterlikova, A. N. (2011). Logistika. Integratsiya i optimizatsiya logisticheskikh biznes-protsessov $\mathrm{v}$ tsepyakh postavok. Moscow, EKSMO, 981.

Работа поступила в редакцию 10.04.2019 2.
Принята к публикации 16.04.2019 2.

Ссылка для цичтирования:

Sarimsakov A., Gaffarov M. Advantages of Logistics Guarantee System // Бюллетень науки и практики. 2019. Т. 5. №5. С. 344-347. https://doi.org/10.33619/2414-2948/42/45.

Cite as (APA):

Sarimsakov, A., \& Gaffarov, M. (2019). Advantages of Logistics Guarantee System. Bulletin of Science and Practice, 5(5), 344-347. https://doi.org/10.33619/2414-2948/42/45. 